\title{
INSIGHTS ON ORIGINAL NARRATIVE FICTION IN THE POLITICAL EMblematics of Diego DE SAAVEDRA FAJARDO, ANDRÉS MENDO, AND FRANCISCO GARAU
}

\author{
DESLINDES DE LA FICCIÓN NARRATIVA ORIGINAL \\ EN LA EMBLEMÁTICA POLÍTICA DE DIEGO DE SAAVEDRA FAJARDO, \\ ANDRÉS MENDO Y FRANCISCO GARAU
}

Antonio Bernat Vistarini

John T. Cull

\begin{abstract}
This study explores the function of several types of narrative fiction utilized by three of the most distinguished political emblematists of the Hispanic Baroque: Diego Saavedra Fajardo, Andrés Mendo (who borrows liberally from the work of Solórzano Pereira) and the expressly anti-Machiavellian works of Francisco Garau. We consider the rationale behind choosing the emblem as a vehicle to express Counter-reformation political thought and we trace an evolution that leads to one of the books of Garau, which reveals itself to be a highly original work that propagates traditional rhetorical procedures and at the same time it conceals a radical skepticism affecting both the form and content of the work.
\end{abstract}

KEYWORDS: Emblems, Spanish Political Literature, Golden Age Literature, Narrative Fiction

\section{RESUMEN}

Este estudio explora la utilización de la ficción narrativa en tres de los emblematistas políticos más destacados del Barroco hispano: Diego Saavedra Fajardo, Andrés Mendo (que utiliza ampliamente la obra de Solórzano Pereira) y la obra expresamente antimaquiavélica de Francisco Garau. Nos preguntamos acerca del porqué de la elección del emblema para verter el pensamiento político contrarreformista y encontramos una evolución que conduce hasta el libro de Garau, donde se hace patente un trabajo original que a la vez que alarga los procedimientos retóricos tradicionales del género esconde un escepticismo radical que alcanza por igual a la forma y al contenido del libro.

PALABRAS CLAVE: Emblemas, política, literatura española, literatura del Siglo de Oro. 
To what extent can a single emblem of the hundreds of thousands of those contained in the more than 6,500 emblem books counted by Peter Daly (2014, pp. 1-11) created throughout the Renaissance and Baroque, be deemed as truly "original"? But we can also posit the opposite question: Is there any emblem that is not totally original? The disjunctive is not as insignificant as it may appear at first glance, since it hints at our basic understanding of what constitutes an emblem. And we can pose the question in yet another way: is the emblem a product or a process? What portion of its spectacular publication success can be attributed to the pen of its creator (that is to say, the totality of the creators who intervened in the manufacture of this multimedia artifact) and what portion should be ascribed to a very particular process of reception? These questions, which have received various responses in the theorization of the emblem inaugurated in the studies of Albrecht Schöne, and continued by Daniel Russell, Peter Daly himself, David Graham, Sabine Mödersheim and many others up to the present time, such as Rüdiger Campe for example, place the emblem within a unique register as an artistic object. ${ }^{1}$

We are not exactly referring here to emblematic dichotomy or polarity, an extreme case of which might be Geoffrey Whitney's book, A Choice of Emblems (Leyden, 1586), which Rosemary Freeman, the foremost expert on Elizabethan and Jacobean emblems, characterized as a work with practically nothing original; while at the other end of the spectrum, and more difficult to offer examples of, we might find one of those alchemical books of emblems such as the Atalanta fugiens of Michael Maier (Frankfurt, 1617-18), ${ }^{2}$ or the Philosopbia reformata of Johann Daniel Mylius (Frankfurt, 1622), which elicit a radical reaction of surprise due to their images and texts that at times strike us as totally unexpected. We seek instead to inquire in some depth as to the mode of composition, selection, articulation and reading of these incredibly special objects that comprise a considerable part of Renaissance and Baroque literature.

We are all aware that the concept of authorship as applied to emblem books is something problematic as far back as 1531 when the Emblematum liber, signed by the jurist Andrea Alciato, appeared in Augsburg, with the decisive intervention of its printer Steyner. Alciato, to a great extent, was nothing more than the translator of some Greek epigrams. ${ }^{3}$ But that apparently simple invention that fuses at minimum

${ }^{1}$ For current bibliography on this topic see Daly 2014, pp. 39-55.

2 See Joscelyn Godwin's prologue to the 2007 Spanish translation of Maier (pp. 11-62), and more specifically on the topic at hand, see Purs 2006, pp. 31-46.

3 See Mino Gabriele's introduction to his edition of Alciato (1999, pp. xxi-xxxiv) and for a more detailed annotation of the 1531 edition, see De Angelis (1984). 
the three well-known elements of pictura, inscriptio and subscriptio soon revealed such a degree of complexity that it had to be integrated into the system of artistic creation and communication - and within the theoretical framework of literary genrestaking into account with very careful consideration its unarticulated characteristics in terms of form, ontology, semantics, functionality and intentionality.

Space limitations necessitate that we restrict ourselves here to a rather narrow focus that cannot take into account the full extent of the process of emblematic invention and elaboration. We have chosen to concentrate on how certain Spanish emblem books that present themselves explicitly as works of political reflection articulated ideas on narrative fiction. At the same time we will analyze the evolution of a mode of exposition of political thought within the emblematic genre, a genre flexible enough to accomodate every conceivable literary ploy and stylistic device.

Claudio Clemente, in his Maquiavelismo degollado (preliminary materials, paragraph 3), seems to distrust the use of exempla, and of historical anecdotes, even when its origin is sacred, for he was acutely aware that they could serve as a very powerful source of deceit when wisely manipulated by those ideologues against whom he waged combat over matters of state. Thus, he affirmed that: "Statists [that is to say, the adherents of Machiavellian reason of State] deceive the common people with a coating of religion, and they make use of it as best suits their interests." ${ }^{5}$ Nonetheless, they can of course be convinced by a convenient counter-attack of "authorities from Holy Scripture and with sacred examples, with the misfortunes of the persecutors of the Church. [] Reigning and conquering depend on the will of God: this is proven by the tribulations of some and the fortunate blessings of others, with some facts and sayings worthy of being written with gilded letters" (ibid., §4). ${ }^{6}$

In this way, from the very beginning of his treatise he availed himself of fiction, and the entire work is thus subject, from this entrance-way, to a narrative

\footnotetext{
4 First published in Latin in 1636, the critical consensus no longer appears to believe that the author's name is a pseudonym for J. Eusebio Nieremberg, as Palau y Dulcet speculated (Hendrickson, p. 203). A recent edition of the Jesuit Clemente has been published by Luis Felipe Jiménez and Antonio Núñez Martínez.

5 "Los estadistas engañan al vulgo con capa de religión, y se valen della como les viene mejor a sus intereses."

6 “...autoridades de la Sagrada Escritura y con ejemplos sagrados, con las desdichas de los perseguidores de la Iglesia. [...] De la voluntad de Dios depende el reinar y vencer: pruébase con los malos sucesos de algunos y felices augmentos de otros, con algunos hechos y dichos dignos de ser escritos con letras de oro..."
} 
illusion in the first person. What is more, he proves to be a narrator who presents himself as being able to hide and dissimulate using the best weapons wielded by those same Machivellians against whom he must wage combat:

With the same determination I endeavored to learn the mysteries of Politicians, so that having uncovered all of their secrets, everyone might come to despise this mortal pestilence of the commerce and dealings of some men with others. This, then, is the reason that excited my curiosity, and this is my plan. In order to execute it, I cannot deny that I disguised myself and I dissembled a little bit, (ibid., p. 17). ${ }^{7}$

Thus a political treatise begins as though it was a short story (the first person narrator does not attempt to hide the fictitious nature of the plot): "Aquí, señor, no es fácil decir lo que vi y las palabras que oí; vi cosas más admirables y oí lo que aún me causó más crecida admiración..." (ibid., pp. 18ff.). ${ }^{8}$ He invents an "experiential" story of a supposed "political" ceremony (using the adjective contemptuously, as with "statist" previously, in order to refer to those defenders of Machiavellian reason of State) that hints at a parody of the Christian liturgy: "Here, sir, it is not easy say what I saw and the words that I heard; I saw even more admirable things and I heard things that increased my admiration even more..." (ibid., pp. 11-12). ${ }^{9}$ Thus, even though this is followed by the standard sort of argumentation found in a treatise of this nature, the framework is a fiction narrated in the first person where the protagonist attends a meeting of "politicians" (also called "pseudo-politicians") belonging to the sect of worshippers of reason of State. With this Clemente inaugurates, on the chronological threshold of the books we are analyzing, and at the apogee of the influence of the Conde-Duque de Olivares (ibid., pp. 122), the articulation of an original fictional narrative as a persuasive model, distinct from the accumulation of exempla and the appeal to authorities (techniques which manifest themselves in very modest quantities in his discourse).

\footnotetext{
7 "Con la misma determinación procuré yo conocer los misterios de los Políticos, para que habiendo descubierto sus secretos vengan todos en aborrecimiento deste contagio mortal del comercio y trato de unos hombres con otros. Esta es pues la razón que excitó mi curiosidad, y aquesta mi pretensión, y para ponerla en execución, no puedo negar que me disfracé y disimulé algún tanto."

8 "Colegí por algunos indicios que estaba cerca el día en que la orden de los Políticos celebraba su principal fiesta: fuime a uno que sospeché era el sacristán y guarda de la capilla de aquel templo, que en más veneración se tenía...."

9 "Aquí, señor, no es fácil decir lo que vi y las palabras que oí; vi cosas más admirables y oí lo que aún me causó más crecida admiración....”
} 
Clemente constructs an imaginary amphitheater in which, hidden, he observes through cracks in the closed door participants in a conclave who ritualistically espouse execrable "Machiavellian" arguments. The exempla and authorities, not even those of Holy Scripture (and perhaps these less than any other), are given no more credit by the "politicians" of such a sect "than the fabulous books of chivalry" (Ibid., 39).${ }^{10}$ Both explicitly and formally, the book contains the negation of the possibility of convincing the sect by means of anecdotes and examples. However, by means of the use of a form of litotes, in which the narrator relates what he will not tell us, it abounds in biblical stories, etc. ("I will not say..., nor will I say..." et passim ["No diré , ni diré"]). Clemente constantly stresses the insufficiency of the anecdote to convince Machiavelli (a historian, lest us not forget):

Once again I ask you, oh Machiavelli: "When you hear and read these things, tell me, upon your faith (if you have any), tell me, do you have sufficient courage and shame, or, better expressed, do you have sufficient madness and impiety to persuade your sectarians that in civil government they should prefer pagan religion to Christian religion?" (ibid., p. 52). ${ }^{11}$

The answer, of course, is yes. This book also passes in review the efforts by the successive heirs of the House of Austria to persevere in a Spanish Catholic monarchy, and the rewards that ensue, and which will continue benefitting the entire orb, as long as they remain steadfast and persevere (see the emphasis on ibid., pp. 141-142).

We have used this text as our point of departure because it reveals, although in an incipient and superficial manner, the presence of an element of fiction in the first person that is suspicious of the efficacy of authorities and the argumentation of treatises to sway political behavior in an anti-Machiavellian direction. In addition, due to its chronological and thematic proximity, it serves as a threshold leading to three Spanish emblematic works with explicit political content that we will comment upon briefly from this particular analytical angle. We will focus then on three works published during the second half of the seventeenth century, in the period between 1642 and 1700, which share common concerns-and responses that are not markedly different-pertaining to the state, the exercise of power by

\footnotetext{
10 "...que los fabulosos libros de caballería."

11 "Aquí otra vez te vuelvo a preguntar, oh Maquiavelo: ¿Cuándo oyes y lees estas cosas, dime, por tu fe (si es que tienes alguna), dime, tienes bastante ánimo y vergüenza, o, por mejor decir, tienes bastante locura e impiedad para persuadir a tus sectarios que en el gobierno civil antepongan la religión gentílica a la cristiana?”
} 
the ruler, and the moral and religious limits of his action. The three books are: Idea de un principe politico cristiano representada en cien empresas, of Diego de Saavedra Fajardo (1642), the Principe perfecto y ministros ajustados, by the Jesuit Andrés Mendo (1662) and the Tercera parte del sabio instruido de la naturaleza, by the fellow Jesuit Francisco Garau (1700).

Indeed, during the period when Clemente was publishing his Maquiavelismo degollado, Saavedra Fajardo was giving shape to the early outlines and drafts that would eventually lead to the Idea de un principe politico cristiano. ${ }^{12}$ The insertion of this work in the genre known as "mirrors of princes" reminds us that the Spanish version of the very influential De regimine principum of Aegidius Romanus, helped to increase the genre's popularity, since its translator, Juan García de Castrojeriz (Glosa castellana al Regimiento de principes, 1494) added some fictional tales to his source material. From that point on, the genre permitted any number of different manifestations of literary fiction, ${ }^{13}$ climaxing in the Relox de principes by fray Antonio de Guevara, a work whose semi-novelistic framing device was inherited from the Libro áureo de Marco Aurelio. Its predilection for novelties- "because things that are old cause disgust, and those that are new whet the appetite"14 — represents a milestone for this type of work typical of secular humanism. The anecdotes taken from more or less certifiable sources, usually ancient historians, give rise to the inclusion of original stories (a fact that does not preclude their incessant censures of the literature of fiction that was gaining in popularity during those years, as was the case with moralists who followed in the footsteps of Erasmus and Juan Luis Vives). In so doing, the Franciscan Guevara-as Emilio Blanco explainswas only making use of similitudo, classified by Cicero in the Topica among the "intrinsic" oratorical arguments, where adducing invented tales is tolerated. ${ }^{15}$

Treatises on the education of princes garnered renewed and vigorous popularity after the publication in 1531 of Machiavelli's The Prince (curiously, the same year as of the first edition of Alciato's Emblematum liber). We will refrain

\footnotetext{
12 An initial version was published in 1640 (Múnich, Nicolao Enrico), with a more definitive edition in 1642 (Milan) that included an additional impresa and a reorganization of the content to provide better continuity in the educational discourse of a prince. We cite from the recent edition of S. López Poza.

13 On this topic see Galino Carrillo.

14 “...porque las cosas viejas ponen hastío y las que son nuevas despiertan el apetito." The quote derives from the Epistolas familiares (I, 10, 72), and is repeated by Blanco in his edition of the Relox de principes (Introducción, p. XXXIII).

15 Cicero, Topica (X, 41-44). See Blanco (ibid., p. LI).
} 
from summarizing the characteristics of works of this type that appeared between 1531 up until the publication of the Idea by Saavedra. ${ }^{16}$ Titles such as Francisco de Monzón's Espejo del príncipe cristiano (1544); Felipe de la Torre's Institución de un rey cristiano (1556); Furió Ceriol's El concejo y consejeros del príncipe (1559), as well as others such as P. Barbosa Homen's Discursos de la juridica y verdadera razón de estado [...] contra Maquiavelo y Bodino y los demás politicos de nuestro tiempo sus secuaces (1626); and, above all, the diffusion of works such as that of Justus Lipsius, Politicorum sive civilis doctrina... (1589, translated into Spanish by Bernardino de Mendoza in 1604), of the Ragion di stato by Giovanni Botero (1589, with an expanded version in 1598), and of the Tratado de la religión y virtudes que ha de tener el principe cristiano by Pedro de Rivadeneira (1595), constitute an impassioned roll-call of widespread works in the Hispanic realm that from very early on debated the ideas of the Florentine historian.

However, as we indicated at the beginning of this essay, casting this incandescent political material (and the others that make up this book) into emblems implies a much more complicated operation than the mere inclusion of some engravings with the addition of a motto at the beginning of each discourse, since the author has abandoned any classical structure of a typical treatise. Starting with the very heading, he privileges instead invention, the association of ideas, sources and concepts, more or less enigmatic allusion and visuality over and above the conveyance of extraneous materials in order to legitimize and put his own stamp on his voice: "I have attempted novelty in the invention, but I do not know if I have attained it...," Saavedra says, and he confesses also to writing "so that the experiences acquired over the course of thirty-four years do not perish with me..." (Saavedra 1992, p. 174). ${ }^{17}$ Likewise, we must bear in mind a relevant fact: Saavedra Fajardo's book is, properly speaking, the first "thematic" Spanish

16 For an overview of the fortune of the genre in Spanish context during the sixteenth and early-seventeenth century, see Truman 1999: 12-31.

17 "He procurado que sea nueva la invención, y no sé si lo habré conseguido..."; "para que no se perdiesen conmigo las experiencias adquiridas en treinta y cuatro años...." Ericio Puteano, in the epistle appended to the end of the book, concurs with Saavedra, placing on a second level, beneath invention, erudition and other elements appropriate to the traditional panegyric: "Other paintings lower down, because for us this is an Apeles who with his wit [...]. Other books lower down: for us, this is a writer..." (ibid., p. 190) [“Abajo las otras pinturas, para nosotros este es un Apeles que con su ingenio [...]. Abajo los otros libros: para nosotros este es un escritor...”]. 
emblem book. ${ }^{18}$ Gómez Martínez ${ }^{19}$ has pointed out the "essayistic" nature of the Empresas; but that would be an obvious, and to a certain extent, limited definition, if we do not stress that we are dealing with a harmoniously intricate discourse. In Saavedra it is essential to pay attention to the tension between the fragment (the "imprese") and the whole (the "idea" of the title), a tension, as we have noted, not previously found in the Spanish emblematic tradition, at least not to to this extent. The pedagogical presentation of the text is the fundamental element that provides cohesion, but it is enhanced by the personal experiences of the author pertaining to the themes that he develops.

In a sense, Saavedra's book is written in the first person. The author hints at this in his dedication to the ill-fated prince Baltasar Carlos: "And because in political materials the discourse can be deceptive if they are not assured by experience of the cases..." (Saavedra Fajardo 1992, p. 169)..$^{20}$ The first person voice cannot fail to be present in a book that adduces a need for the implication of personal experience, and which, above all, is the result of a codex excerptorius that the author has been nourishing and polishing throughout his life.

Thus the "I" (in a dialogical connection with the "you" of the prince as the explicit recipient) is sprinkled here and there throughout the paragraphs. We also note a frequent doubling back to the author's present in the anecdotes related. This tends to happen, significantly, at the end of the impresa. In a good number of them the final paragraph features the first person voice, upon which rests as a closure upon which the discourse rests and takes its ultimate meaning. We find this strategy utilized, with diverse formulas, in the conclusion of the following 28 imprese; that is to say, in almost a third of the total number: 1, 5, 9 (with an abundant use of the first person on the theme of envy amplio), 12 (a direct observation on the atrocities of war), 22, 24 and 29 (all three of which apply

18 Obviously there are other books that might be characterized as thematic, but whose emblematic content is greatly reduced, such as those by Francisco de Guzmán (1565), C. Pérez de Herrera (1598 and 1618), or books dedicated to the chronicling of public festivals or the description of funeral exequies such as that of M.A. Ortí (1640) or the anonymous Libro de las honras de Maria de Austria (1603). Perhaps a portion of J.F. de Villava's book (1613), in spite of its disorder, might be argued to have predated Saavedra's contribution as the first Spanish emblem book to be organized along certain thematic lines of continuity.

19 Gómez Martínez unpaginated web edition. See also the clarifications of Neumeister on this topic (1998, pp. 321-32).

20 "Y porque en las materias políticas se suele engañar el discurso si la experiencia de los casos no las asegura...." 
the discourse to current history), 32 (discourse in first person on the book's intentions, pp. 446 and 449), 33 (manifestation of personal experience, p. 454), 39, 43, 45, 47, 50, 54, 57 (a more "literary" ending of this last one, and of personal reinforcement by means of quoting some lines from Tasso: "I close the discourse of this impresa," pp. 703-4) ["Cierro el discurso de esta empresa"], 60 ("I close this material with two warnings," p. 716) [“Cierro esta materia con dos advertencias”], 66 (presence of the first person in the reflection on science and the convenience of study for the ruler, p. 755), 69 a very personal impresa on the development of economic ideas, and also in the first person, on the value of money, etc.), 87 ("Over the course of a few years we have seen," pp. 933 and 935) [“En pocos años hemos visto"], 89, 90 ("From everything that has been said, one infers...," p. 951), ["De todo lo dicho se infiere"] —an impersonal expression that should of course be interpreted as personal: "I infer"—: 91 " "I do not pretend that with this doctrine...," p. 958) ["No pretendo con esta dotrina"], 94 ("I well believe...," p. 981) ["Yo bien creo"], 95 (first person discourse on the Italian conflicts with which Saavedra was intimately acquainted, concluding once again with recourse to personal experience: "From everything stated one infers...," p. 989) [“De todo lo dicho se infiere"], and 97 (direct advice once again on Italian politics: "Therefore it seems convenient that the maxims of Spain be implemented in Italy," (p. 1006) ["Por esto parece conveniente que en Italia se muden las máximas de España"].

While it is true that Saavedra does not include fictional tales in the strictest sense of the term, his choice of the emblematic genre-which is fragmentary, replete with conceits, cognitively demanding for the reader and marked by a strong desire for rhetorical inventio (given its articulation of pictura and inscriptio plus the extended development of a sententious prose element)—results in a lively theoretical discourse on a literary level that is far superior to any traditional exposition of ideas on the political state and the behavior of the ruler. The word "Idea" in the title thus acquires a much more complex meaning.

The next author of an emblematic political treatise in Spanish is the Jesuit Andrés Mendo. We cannot state that his Principe perfecto y ministros ajustados (1662) ${ }^{21}$ manifests the same desire for originality as the work of Saavedra Fajardo, nor that it shares the same quality. This is because, in the first place, as Beatriz Antón has

21 A first and unillustrated edition, later repudiated by its author, appeared in Salamanca (Diego Cossío, 1657); and a printing almost identical to that of 1662 issued a year earlier from the same lyonnaise press. Critics as well as the author himself consider the 1662 edition to be the editio optima. 
demonstrated, it is almost in its entirety a Spanish version of the Latin emblems composed by Juan de Solórzano Pereira, ${ }^{22}$ but also because on the whole, its author presents much more limited literary ambitions.

The differences between Mendo (Solórzano) and Saavedra are substantial. The former's elimination of "I" is almost total, as a result of which we find a parallel revalorization of history over experience: "History teaches more in a short time than experience in much time" (Mendo, p. 99), ${ }^{23}$ he asserts, recommending its reading to the ruler. He reinforces this notion, in fact, with a historical anecdote on king Alfonso V taken from the Dichosy hechos de Alfonso, rey de Aragón by Antonio Beccadelli, il Panormita: "having fallen ill in Capua, he read the history of Alexander the Great by Quintus Curtius Rufus, and he attributed the curing of his illness to this diversion, and said that neither Avicenna, nor Hippocrates, but rather Curtius, had restored his health." ${ }^{24}$ Nevertheless, by restricting his anecdote to the discourse proper, Saavedra Fajardo is much more strict than Mendo. Between the first and second editions of his book, Saavedra eliminated the majority of the mythological references, while in Mendo the recourse to mythology is widespread, at times mixed in indiscriminately among other anecdotal sources. Thus il "Documento 27" ("Let him not allow excessive delicacies, which are the ruin of kingdom" ["No consienta delicias demasiadas, que son la ruyna de los reynos"]), he includes Hercules in the same enumerative paragraph of historical examples, without concern for continuity and as though they belonged in the same category, between an anecdote on the emperor Heliogabalus and the recollection of recuerdo de "the loss of our Spain when it was occupied by the Saracens" ("la pérdida de nuestra España quando la ocuparon los sarracenos"): "Hercules besmirched his glorious labors by effeminizing himself lasciviously with his obsession with Omphale in Lydia" (Mendo 139) [“Escureció Hércules sus gloriosos trabajos afeminándose

\footnotetext{
${ }^{22}$ For information on the rather improbable edition of 1651 and other details on the life and works of the author, his direct relationship with Mendo's book and a detailed bibliography, see Antón 2008, pp. 249-67. Nevertheless, it should be stressed that such relationships, when we are dealing with emblematics, do not invalidate a given book's originality since, to a certain extent, any stray element is new and original once it is inserted into the emblematic artifact. A very interesting case to help illustrate this one is George Wither's appropriation of the emblems of Gabriel Rollenhagen.

23 "Más enseña la historia en poco tiempo que la experiencia en mucho."

24 " $[. .$.$] que aviendo enfermado en Capua, leyó la historia de Alejandro Magno en Curcio, y$ atribuyó a este alivio haber sanado de la dolencia, y dixo que ni Avicena, ni Hypócrates, sino Curcio, le avia restituydo la salud."
} 
deliciosamente con la afición de Omphales en Lydia”]. It should not surprise us therefore to find that Mendo reveals himself to be an attentive reader and admirer of fray Antonio de Guevara (Mendo, Documento 32, p. 158). If in Saavedra there is practically no mythological invention, in Mendo it is the primary theme of emblems 3, 4, 10, 11, 15, 18, 19, 20, 23, 26, 34, 38, 49, 51, 58, 65, 72, 76, 77 and 79. The animalistic story of a fantastic nature can be found in emblems 22 and 24 . The issue planted by the utilization of such devices in these treatises in an emblematic context is somewhat complex. We can best formulate it in the words of Peter M. Daly when he calls into question the concepts of veracity and falsehood, of reality or fiction, in emblematic materials:

Do we believe as true what we see in emblematic pictorial motifs, which may inform either or both picture and text(s)? Do we believe in the truth of the snake swallowing its tail, the bear licking its unshaped cub into form, the pelican sprinkling its own blood on its chicks, the salamander flourishing in fire, the phoenix being reborn from its own ashes? Readers can extend the list almost indefinitely. Truth is not necessarily only validated by science, logic, mathematics, observation, experimentation or so-called objectivity" (Daly, pp 46-7)..$^{25}$

${ }^{25}$ It is worthwhile to heed the considerations raised throughout this chapter, entitled "Truth in emblems." López Poza is justifiably perplexed by a line of commentary from Saavedra's impresa 9, when she states that "this image is not easily understood" ("no se entiende bien esta imagen"): "Exposing its eyes to the rays of the sun, the owl provokes emulation and envy in other birds. They would not persecute it if it enclosed itself in the oblivion and shadows of the night” (Saavedra Fajardo, p. 262) [“El sacar a los rayos del sol sus ojos el búho causa emulación y envidia a las demás aves. No le persiguieran si se encerrara en el olvido y sombras de la noche”]. The fact is that we should not always expect in emblematics the primary and traditional meaning of a given symbol, but rather its manipulation. Daly comments thus on a similar case found in Georgette de Montenay: "Georgette de Montenay has an emblem in which eagles peck at a carcass. De Montenay doubtless knew her Bible better than most of us do. She would have known the biblical passages that relate eagle to carrion, carcass, body, and prey (e.gr., Job 9:26, Matthew 24:28 and Luke 17:37). How that relationship is illustrated raises different questions. The Henkel and Schone Handbuch wrongly identifies the birds in de Montenay's emblem as vultures (Geier) although the emblem writer herself names them eagles (aigle) in her subscriptio. Whether eagles actually feed on carcasses, as do vultures, may not be relevant. One should not necessarily expect accurate nature information from all emblems. Does 'accurate' only mean according to the most modern knowledge available at the time? The information underlying many a nature motif in an emblem may not have been based on the then most modern scientific information available. In fact often some other tradition such as the Bible may have been the emblem writer's source or authority, if unstated rather than scientific observation. This would also apply to the eagle emblem by de Montenay" (Daly, p. 51). 
The truth or falsehood, the reality or fiction of an example adduced is not as important to the emblematist as the lesson (moral, political, religious, etc.) that can be extracted from this piece, from this "tessera" ("emblem") of human understanding exposed before our senses and which, along with the others, makes up a great argumentative mosaic. Once again, the choice of the emblematic structure and invention enriches and makes more complex the mere political lesson as it would have been developed in a treatise, imbricating it with forms of the imagination where a certain suspension of certainties and univocal interpretations is produced.

However, the author who without doubt carried to an extreme the possibilities of the emblematic genre with fiction and political discourse was the Jesuit Francisco Garau and, most particularly, in the fourth of his series of emblem books: the one whose very title reveals the most explicitly political content. In itself it constitutes a complex declaration of intentions: Tercera parte del sabio instruido de la naturaleza, con esfuerzos de la verdad en el tribunal de la razón, alegados en cuarenta y dos máximas políticas y morales, ilustradas con todo género de erudición, sacra y bumana, contra las vanas ideas de la política de Maquiavelo (Barcelona: Cormellas, 1700). ${ }^{26}$

Francisco Garau was born in the Catalonian city of Gerona in 1640, a year of turbulence, wars and uprisings on the Iberian peninsula, with the revolt of Catalonia and the proclamation of of the Portuguese Restoration. At the age of 15 , on November 8th of 1655 , he entered into the Jesuit novitiate. His studies and dedication to the Society of Jesus resulted in his teaching of humanities and theology, initially, and later to his appointment as censor for the Inquisition, and then Rector of Jesuit colleges in Barcelona, Urgell, Mallorca and Zaragoza. His principal creative production, enormously popular and widely disseminated, consisted of the four titles on moral-political themes developed from the point of departure of a very Baroque integration of sources deriving from emblematics,

${ }_{26}$ There is no incongruence in the numbering. It is the third book of the series "El sabio instruido de la naturaleza" but the fourth of his emblem books. In this case, and different from the previous ones, it includes illustrations from its very first edition of Barcelona, 1700, a scheme maintained in the subsequent editions of Zaragoza, 1704; Madrid, 1710 and Barcelona, 1712. His third emblem book was El sabio instruido de la Gracia. This was published in two volumes based on earlier unillustrated editions (Barcelona, 1688 and 1690) to which engravings would later be added: Olite, 1693; Barcelona, 1698, 1703 and 1711 y Madrid, 1709. This work was translated into Latin in two unillustrated editions: Sapiens a divina gratia instructus... in ideis evangelicis ac moralibus, Ingolstadt, 1731 and 1732. In other studies we have detailed the editorial history of the production of this Catalan Jesuit. 
the literature of fables, exemplary literature and homiletics. He died in Barcelona on July 10th of 1701.

Garau's body of emblematic works, the series of El sabio instruido, respects for all practical purposes the formal scheme of Spanish emblematic literature of the seventeenth century, with its tendency to include a lengthy and discursive prose amplification. It is worth noting that the picturae, which tend to be more narrative vignettes than synthesizing symbolic representations, are directly related to the prose content in the subscriptio which Garau in fact terms "Ficcion." This "Fiction" is, as a general rule, a stylistically Baroque reworking of fabulist literature, ${ }^{27}$ most notably the apologues of Aesop, and typographically distinguished by the use of italics in the ficcion proper. The illustrations are not included in all editions, perhaps because in its origins the book may have been conceived of primarily as more a collection of maxims, dicta et facta, or commonplaces designed as an aid to sacred preaching, rather than as pure emblem books. But subsequently he clearly abandoned his initial plan. Immediately following the "Ficción," which appears beneath the pictura, we find in cursive a sententious enunciation termed "Máxima," that summarizes the general moral or political content, which is then elaborated upon in an always lengthy and sometimes sinuous prose commentary. [Figure 1] In addition to extensive scholia in Latin in the margins and at the bottom of the page, Garau often includes pithy remarks or glosses in Castilian in the margins, perhaps as a didactic tool or as a mnemonic device. The sources of the scholia include fabulistic and moral literature, the Bible, Patristic and Senecan literature, collections of aphorisms, modern and classical historians, etc. However, Garau reveals his adherence to emblem literature in the very introduction to El Sabio instruido de la naturaleza, accentuating the distance between his work and that of some other emblematists that preceded him.

It is for this reason that our point of departure was a questioning of the originality of these works, since the evolution of the emblem books of Francisco Garau offer some interesting points of reflection. Let us begin with the process of introduction and the subsequent evolution of the meaning of the picturae. The first edition of the Sabio instruido de la naturaleza appeared without illustrations, but the structure of the book and the manner of presenting its content point towards

${ }^{27}$ On the relationship between emblem and fable, with considerations on Garau, see Bernat Vistarini 2001 and Bernat Vistarini and T. Sajó 2007, pp. 83-91. This relationship has been the object of a number of studies, including that of Paul J. Smith, with the most current bibliography (2005, pp. 161-85). 


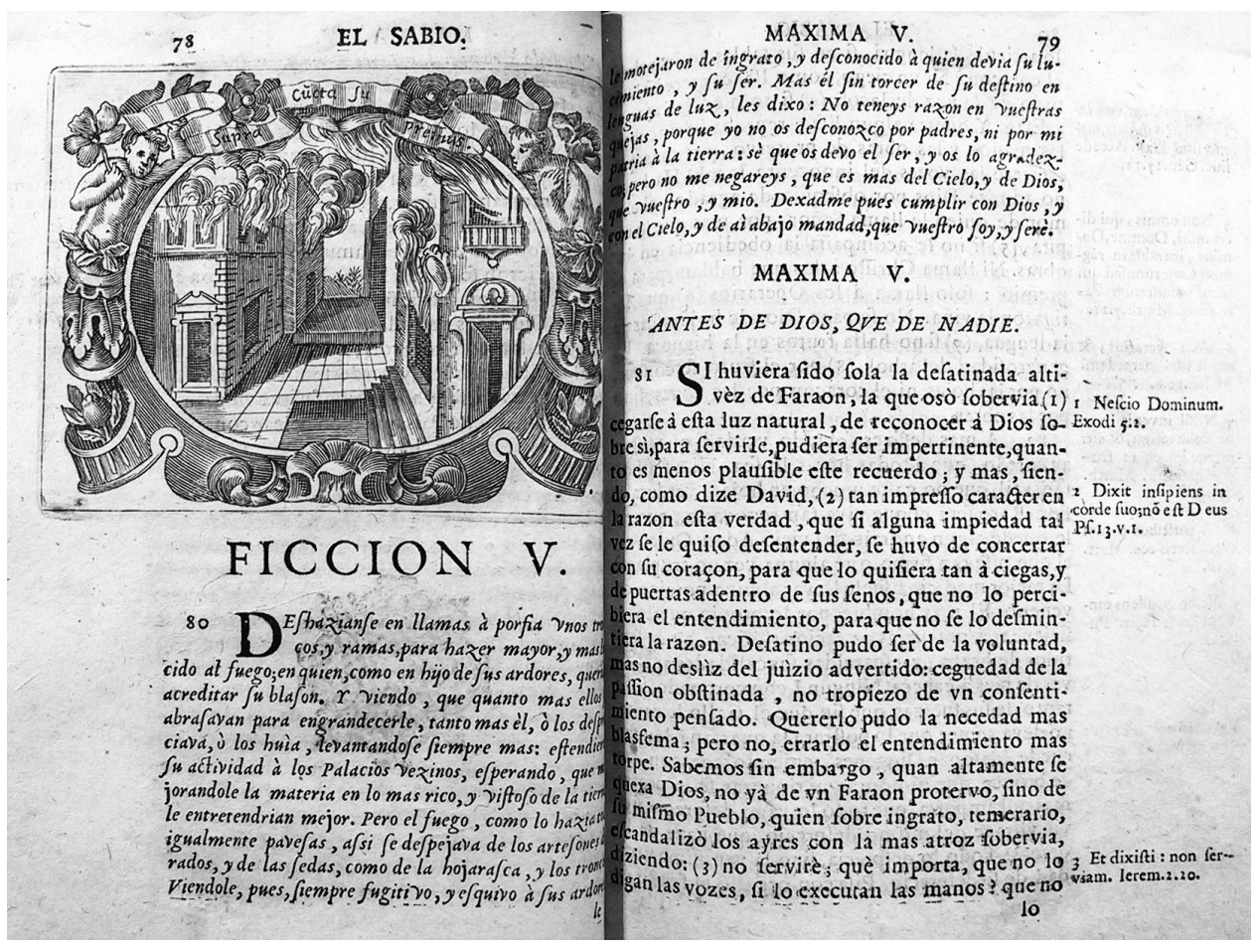

Figure 1. Francisco Garau,Tercera parte del sabio instruido de la naturaleza, con esfuerzos de la verdad en el tribunal de la razón, alegados en cuarenta y dos máximas politicas y morales, ilustradas con todo género de erudición, sacra y bumana, contra las vanas ideas de la política de Maquiavelo. Barcelona: Cormellas, 1700, 78-79.

an emblematic reading. And, in fact, we can perceive this clearly beginning with the edition of 1690 , which includes the picturae in order to perfectly complete the composite. The emblem does not require originality in any of its constituent parts in order to give rise to an original artefact in its entirety. In fact, we have not mentioned up to this point an observation readily apparent to anyone familiar with the emblematic tradition and the most popular of the Renaissance and Baroque emblem books: a good number of the illustrations of the editio optima of the Sabio instruido de la naturaleza (Barcelona, 1691) are copied from Joachim Camerarius's Fabulae Aesopicae (Lyon: Jean de Tournes, 1571).

This beautiful 1691 Barcelona second printing offers a series of new woodcut prints, more highly ornamented, better carved and each with its corresponding inscriptio, which were previously lacking. In addition, the author adds occasional 
phrases or paragraphs not included in previous editions and which expound especially upon the religious references. All of the emblem books by Garau have in fact unillustrated first editions, with the exception of El sabio instruido, which, curiously, is the book whose content is most explicitly tied to political persuasion and with a pragmatic intent. As a consequence, this is the only one of the four books in the series that was born as a fully finished emblem book. This is no doubt intentional. In this book, the last one in the series, Garau has taken his technique to an extreme, and he has clearly mastered his expressive devices with much greater creative freedom.

After the interlude afforded by The Wise Man Educated by Grace ("El sabio instruido de la Gracia"), Garau returns here to Nature as teacher. At least that is what the title declares. But if we examine the content carefully we find that eight of the emblems $(1,4,8,13,22,30,35$ and 39) have a mythological content and four others can be characterized by a direct presentation of human behaviors (7, 11, 15 and 26). What is true, however, is that in every case the narrative tale is invented by the author on the foundation of a more or less familiar source: a symbol, and animal trait, a mythological element or character, which provide a point of departure in order to exercise his inventive imagination.

Let us consider just one example of Francico Garau's witty technique, taken from the Tercera parte del sabio instruido de la naturaleza. In emblem 5 he creates a fable following the basic scheme of the personification of some natural elements. In this particular case they are not animals but rather burning wood and the fire it produces, which enter into dialogue:

Some trunks and branches were insistently consumed in flames in order to make the fire greater and more resplendent, and the flames, as the progeny of the fire's vigor, wanted their blazon to receive due credit. But upon seeing that the more that they raged in order to aggrandize the conflagration, the more it either disdained them or fled from them, they elevated themselves even higher, and extended their activity to nearby palaces, in the hopes that by improving the material consumed to include the most exquisite and gaudy to be found on earth, they would better sustain it. But the fire, which rendered everything it encountered into equal cinders, ravaged without differentiation the gilded vaulting and silks of the palace as well as the withered leaves and coarse trunks. Thus seeing the fire to be fleeting and scornful of their burning, the flames accused it of being ungrateful and forgetful of those responsible for its brilliance and being. But the fire, without deviating from its destiny, in tongues of light said to them: You have no right to complain, for I do not deny you as parents, nor do I deny the earth as my homeland. I know that I owe you my existence and I am grateful to you for it; but you will surely not 
refute that it is owing more to Heaven and God than to you or I. Thus allow me to render unto God and Heaven and be happy with ruling all that is below, for I am yours, and I will always be GOD's BEFORE ANYONE ELSE's (Garau 1700, $\$ 80$, p. 78$) \cdot{ }^{28}$

As in all other cases in this book, Garau composes an absolutely personal tale, but of a fabulistic nature. It is important to emphasize that this fable, the "Ficción," in the manner of an apologue or exemplum, precedes the explanatory discourse. And there is certainly no explicit allusion to Machiavelli in this emblem. The pieces of the puzzle are jumbled and it is the reader who must put them together and finish its articulation. Garau was very clear on this point in the prologue or "Razón de la obra" of his previous book (El sabio instruido de la Gracia): it is the reader who must recompose the discourse with the varied materials offered by the author, and the reader must work assiduously and wittily to weave the fragments together. Only then can the reader apply the knowledge extracted, as was the process with Gracián as well, adjusting it in a flexible matter according to the circumstances. In this book the sensation of it being a puzzle is accentuated by the fact that each paragraph of the lengthy explanations in a prose imbued with citations and erudition is numbered consecutively from the beginning to the end of the book (502 paragraphs), as though he wanted us to know that there was a connecting thread underlying the forty-two chapters. That tension detected between the fragment and the whole in the book by Saavedra is even more intense here. The emblematic syntax is of course manifest: "I reveal only the concepts/ conceits that might be useful to you on a given occasion. I do not chew them up

\footnotetext{
28 "Deshacíanse en llamas a porfía unos troncos, y ramas para hacer mayo, y más lucido al fuego, en quien, como en hijo de sus ardores, querían acreditar su blasón. Y viendo que cuanto más ellos se abrasaban para engrandecerle, tanto más él o los despreciaba o los huía, levantándose siempre más extendieron su actividad a los Palacios vecinos, esperando que mejorándole la materia en lo más rico y vistoso de la tierra, le entretendrían mejor. Pero el fuego, como lo hacía todo igualmente pavesas, así se despejaba de los artesones dorados y de las sedas como de la hojarasca y los troncos. Viéndole, pues, siempre fugitivo y esquivo a sus ardores le motejaron de ingrato y desconocido a quienes debía su lucimiento y su ser. Mas él sin torcer de su destino en lenguas de luz, les dijo: No tenéis razón en vuestras quejas, porque yo no os desconozco por padres, ni por mi patria a la tierra. Sé que os debo el ser y os lo agradezco; pero no me negaréis que es más del Cielo y de Dios que vuestro y mío. Dejadme pues cumplir con Dios y con el Cielo, y de ahí abajo mandad, que vuestro soy, y seré... ANTES DE DIOS QUE DE NADIE."
} 
in Sermons, so that you will have the pleasure of making them your own with your wit" (Garau 1709, "Razón de la obra," unpaginated). ${ }^{29}$

In addition, from his very first book Garau adheres to the irreplaceable value of the exemplum, of the moral tale as superior to any kind of argumentative discourse, since only in this manner can the excessive subtleties, potentially pernicious, be unpacked before the reader's eyes and ears. He is thus able to demonstrate with evidence that which can only be attained laboriously by means of the syllogism or the precept. He says that "philosophers, with the rigid severity of their laws and the imperiousness of their precepts, stirred up antagonism between what was endearing and pleasant among the virtues," while on the other hand the authors of fables managed to "sugarcoat theirs so sweetly with the smoothness of their fictions that the wit is left no less tasty than the will is left enamored of knowledge" (Garau 1691, "Introducción," unpaginated). ${ }^{30}$ From a rhetorical point of view Garau is an adherent of a concrete variation of the exemplum. As is known, according to his material sources, we can distinguish among the historical exemplum - which of course corresponds to history-, the poetic type-which originated in the fable - and the verisimilar exemplum — which deals with materials from drama. The first of these is the most prestigious because it is based on truth. The quarry from which it is mined is novelistic historiography, which provides abundant material of this type ${ }^{31}$ and which we find in great volume in many other emblem books of this type, and even in para-emblematic genres such as engraved medallions or numismatics. But Garau, even when he is addressing themes presumably so political, and attempting to prove Machiavelli wrong, tends to make use of the invented exemplum, the poetic variation, which appeals in the first place and in a suggestive manner to sensory perception and to the poeticized experience of the world. From the moment in which the rhetorical system, that

29 "Descubro no más los conceptos, de que pueden servirte en la ocasión. No te los masco en Sermones, porque tengas el gusto de hacerles tuyos con tu ingenio." For some examples of the kind of ideal "proficient" reader envisioned by Garau, see Ledo 2015, pp. 103-112.

30 "Azucarar tan dulcemente los suyos con la suavidad de sus ficciones que no deja menos saboreado el ingenio que enamorada de la sabiduría la voluntad."

31 Lausberg 1990, SS411-412. We are in basic agreement with Blanco's explanation of the discrediting of the classical utilization of the exemplum in the works of Gracián, a notion that could also be applied to the Jesuit Garau in spite of the abundance of exempla in his prose argumentation. In our opinion, it is precisely this discrediting that leads to the unique articulation of the books that make up the entire series of the Sabio instruido de la naturaleza. See Blanco 2006, pp. 47-60. 
places the exemplum within the argumentation, seeks proof from the outside, at the periphery of the data that the argumentation in question is deducing, a path of freedom is opened, the limits of which are difficult to locate. In full control of his artistic resources, Garau does not need in this book anything more than a marginal dependence on images that are almost primordial (we have just seen an example with the protagonist's fire, but we find others in the sea and rivers), on almost trite mythological characters (Apollo, Daedalus, Fortune...), in animals deriving from a basic Aesopic or naturalistic tradition (the fox, but also the scorpion, the salamander in the midst of flames, the stellion with its skin covered in stars, the serpent with the sought-after carbuncle on its forehead...) in order to liberate his imagination and set loose a chain of fictions of his own invention. ${ }^{32}$ [Figure 2]

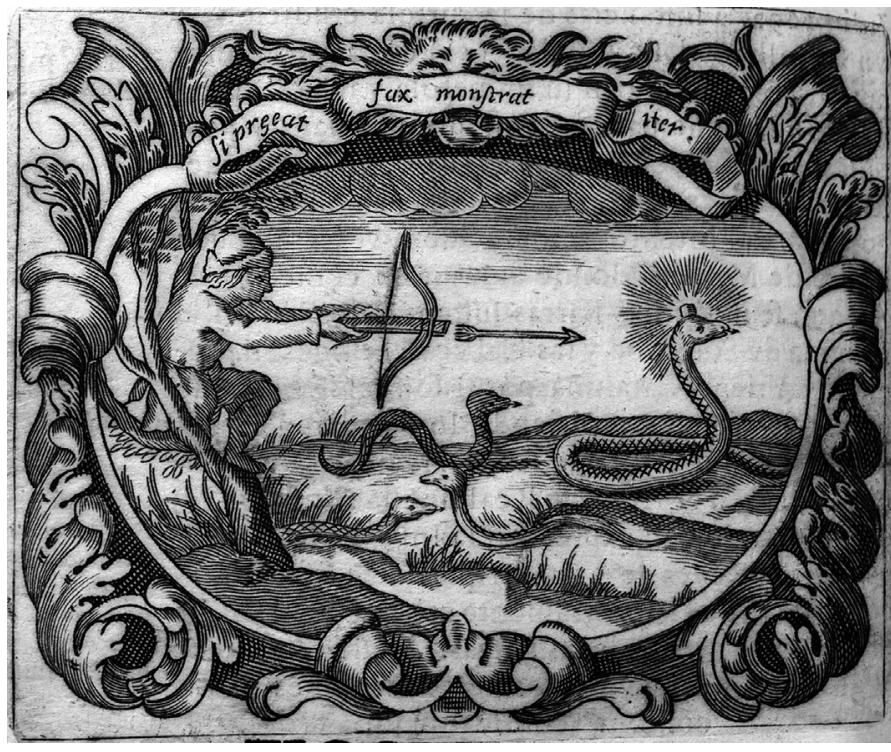

Figure 2. Francisco Garau, Tercera parte del sabio instruido de la naturaleza, con esfuerzos de la verdad en el tribunal de la razón, alegados en cuarenta y dos máximas politicas y morales, ilustradas con todo género de erudición, sacra y bumana, contra las vanas ideas de la politica de Maquiavelo. Barcelona: Cormellas, 1700, «Ficción 33», 415.

32 One of the great paradoxes of the entire series of the Sabio instruido de la naturaleza is its limited contribution to knowledge derived from nature, since Garau deals with poeticized nature, with the fable, or with the moral lesson. And it could not have been any other away at that particular moment of Spanish culture, since animalistic treatises such as that of Ferrer de Valdecebro (as well as his subsequent treatise dealing with birds) functioned in the same manner. A similar limitation, perhaps even more rigid, can be appreciated in the same author's Elporqué de todas las cosas (1668=2007, pp. 17-43). 
Of course, the emblematic construction of Garau does not stop here. The fiction is followed by a veritable waterfall of exempla of a historical nature that are linked together in the subsequent gloss. His associative process of anecdotes is so far-reaching at times that it bears resemblance to the interior monologue of a historian in a trance. It should not surprise us therefore to find in this book an entire chapter dedicated to the superiority of the exemplum over any other kind of lesson. It is Emblem 33, where we find a radical distrust of words:

What is certain is that a mute man not infrequently explains himself better with his actions than the greatest orator with his words. Everyone understands the language of an exemplum and it convinces all. Reasons articulated with the voice suffer objections or are not understood at times (Garau 1700, \400, p. 423). ${ }^{33}$

And by contrast, Garau expresses pedagogical, mnemotechnic and definitive faith in the exemplum:

The habits of good or evil are not transfused so much with blood as they are by way of example. What is the tiny eaglet to do when he sees his mother fix her gaze on any other light than that of the Sun? What is he to do but stare at its circle as well? It is difficult to forget and unlearn that which is taught domestically when one is wrapped in swathing-bands Therefore a wise man said that parents only give to their children through blood, a state of being hardly advantageous to that of brute beasts, but in a good example, which is the most powerful education, they can and should give as do angels, and it would be more beneficial to deny them that life, than to take away from them the use of understanding and reason. Let Princes be vessels of gold and fine porcelain due to their august preciosities; but have them always remember that in their formation they are but clay made from common mud, and that they will always reek of the odor and taste of that first juice of which they drank, whether it ne regal nectar or poisonous hemlock (Garau 1700, \ 386, pp. 407-08). ${ }^{34}$

33 "Lo cierto es que no pocas veces se explica mejor un mudo con sus acciones que el mayor hablador con las palabras. La lengua de un ejemplo todos la entienden y convence a todos. las razones de la vOz o padecen sus objeciones o no se alcanzan a veces."

34 "Las costumbres del bien, o el mal, no tanto se transfunden con la sangre como por el ejemplo. ¿Qué ha de hacer una pequeña Águila que ve su madre se digna de fijar los ojos en otra luz que en la del Sol? ¿Qué ha de hacer sino mirar su rueda también? Es difícil olvidar y desaprender lo que en las fajas domésticamente se aprende. Por eso decía un cuerdo que los Padres solo dan al hijo en la sangre, un ser poco ventajoso a los brutos; mas que en el buen ejemplo, que es la más poderosa educación, se lo pueden y deben dar casi igual al de los ángeles: y sería favorecerles más no darles aquella vida, que quitarles del uso del entendimiento, y razón. Sean 
Garau's book was not so much written to give a concrete anti-Machiavellian explications (which is lost, and drowned beneath the book's rhetorical machinery and whose exposition of the problems of the contrary doctrine of reason of State, at this late point in the century smacks of a worn-out and trite discourse, with no possibility whatsoever of being even remotely original) as it was to exhibit a way to use knowledge, to warn the reader and open his eyes to the difficulty (so characteristic of the Baroque) of articulating a discourse about the world (the very discourse that the Sabio instruido de la naturaleza attempts to forge). It is a book that shows us how to convert the world into a lesson. And, obviously, within the concept of "world," "fiction" is also included, that is to say, the dramatization of the doctrine of Nature; the meeting point where far beyond the ideas of Machiavelli or of any other human being, will and the designs of God are made manifest. A Deus pictor, a God who is also poet and author of that great book that we inhabit and which enters us through the senses if we train them properly. This is the point at which the anti-Machiavellianism of Garau's book begins and ends. With this baggage, how could "nature" possibly oppose Machiavelli? The rest is stuffing.

As we have indicated on another occasion, and which still seems applicable when reading his most political work, Garau attempts, from the very first lines of the Sabio instruido, to establish the coincidence between the real world and the rhetorical model of the book. The point of departure is a topos that he repeats in the first prologue:

Dear reader, he who said that this world was a vast book in whose spacious pages in characters of various colors divine wisdom has been given to us to study, said it well. The nature of every creature is a hieroglyph, and each hieroglyph codifies a document for good living. There is no doubt that he who understands the language of Nature and knows how to listen to its voices will emerge from this course of study prudent, just, strong, temperate, and to summarize it all in one word, wise (Garau 1691, "Introducción," unpaginated). ${ }^{35}$

los Príncipes vasos de oro, y porcelanas finas por sus preciosidades augustas; pero acuérdense que siempre en la formación son de barro, se amasan de lodo común y les dura siempre el olor y el sabor del primer jugo que bebieron, o sea néctar real o ponzoñosa cicuta."

35 “Dijo bien, lector mío, el que dijo que era este mundo un libro grande en cuyas páginas espaciosas con caracteres de varios colores ha querido dársenos a estudiar la sabiduría divina. Es cada naturaleza de las criaturas un jeroglífico y en cada jeroglífico se cifra un documento de bien vivir... No hay duda que quien le entendiere la lengua a la Naturaleza y supiere escucharle las voces saldrá de este estudio prudente, justo, fuerte, templado y por decirlo de una vez, sabio." 
Beginning with the ancient idea of the world as a book, ${ }^{36}$ Garau makes use of emblematics in order to structure his book as the world, and follows, in the presentation of his text, the same cognitive steps by which the world allows itself to be understood by us: the prerequisite intervention of the senses to allow knowledge to enter is depicted in the visuality of the pictura. The emblematic pictura both hides and reveals a "Fiction," that is to say, a moral tale that introduces elements that are in appearance purely natural or mythological and independent of man, in human history ${ }^{37}$ and, therefore, in the history of salvation, an aspect that will subsequently be developed in the gloss: the intellectualization and erudite development that is at the same time useful in his desire to establish precepts and reinforce the chain of transmission of this knowledge In this expositive procedure Garau intersperses the anti-Machiavellian criticism of the entire work, the triumph of Providence in the face of Fortune (the theme in fact of the very first emblem of the book) and of Christian virtue in the face of the excesses of Machiavellian tacticism.

We believe that the discrediting of the exemplum along with a disillusionment as regards the validity of the historical anecdote, in combination with a lack of originality in form and style and an inability to explore in a deeper way the "instruction from nature" that the title proposed (privileging a "Fiction" that prepares us for the deceit and trickery hidden in the very root of the world), make Garau's book quite noteworthy during the late Hispanic Baroque. In it he intuits, with great clarity, that in the final analysis, a "melancholic prince" (Orobitg 1998) is the only option to stand in opposition to Machiavelli's prince, in a kingdom that is not of this world. Let us not forget, finally, that in 1700 , the year of the

36 The bibliography on the notion of the world as a book from the Middle Ages to the Baroque is extremely abundant. This allegorical mode of reading attains special relevance and nuances in emblematics, culminating, as we have seen in the practice of Garau. From the pioneering study of Curtius (1955), up until that of Blumenberg (2000), there are so many others that are worthy of mention. We will limit ourselves here to recommending that of Rodríguez de la Flor (2002) and its bibliography.

37 On this point it is crucial to bear in mind the negative sense of "fiction." Its foundation of deceit is clearly present in Garau's mind when he utilizes the term and it is key to understanding how he opposes it to Machiavelli. Examples are extremely abundant. Martínez de la Vega, in the section "Al lector" of his account of the public festivals in Valencia honor of the beatification of Saint Thomas of Villanova, explains how one should read his text: "If you approach it with fiction, I pardon you; if you do so with peace, read and pardon" (fol. 4v) ["Si llegares con ficción, yo te perdono; si de paz, lee i perdona”]. 
publication of this Tercera parte del sabio instruido de la naturaleza, Charles II was dying, and along with him, an entire era of Spanish politics.

\author{
Antonio Bernat Vistarini \\ Universitat de les Illes Balears \\ antonio@emblematica.com \\ John T. Cull \\ College of the Holy Cross \\ jcull@holycross.edu
}

\title{
BIBLIOGRAPHY
}

Alciato, A. (1531): Emblematum liber, Augsburg: Augustae Vindelicorum Steyner.

ANTÓN, B. (2008): "Los Emblemata centum regio politica (Madrid, 1653) de Juan de Solórzano," in R. García Mahíques and V. Zuriaga Senent (eds.), Imagen y cultura, Valencia: Generalitat Valenciana, I, pp. 249-267.

Bernat Vistarini, A. (2001): "Emblema in fabula. El sabio instruido de la naturaleza de Francisco Garau," in A. Bernat Vistarini and J.T. Cull (eds.), Los días del Alción. Emblemas, Literatura y Arte del Siglo de Oro, Palma: Olañeta-UIB, pp. 83-91.

BERnat Vistarini, A. and T. SAJÓ (2007): "Imago veritatis. La circulación de la imagen simbólica entre fábula y emblema," Studia Aurea (2007), URL = http://www.studia aurea.com/pdf/070625110849_ImagoVeritatis.pdf. [6-7-2017].

BLANCO, E. (2006): "Del dicho al hecho, o la invalidez del ejemplo: el caso de Gracián," Dicenda. Cuadernos de Filologia Hispánica, v. 24, pp. 47-60.

Blumenberg, H. (2000): La legibilidad del mundo, Barcelona: Paidós.

Camerarius, J. (1571): Fabulae Aesopicae, Lyon: Jean de Tournes.

CiCERO, M.T. (1960): Topica, London—Cambridge: William Heinemann—Harvard University Press.

ClEMENTE, C., S.J. (1637): El maquiavelismo degollado por la cristiana sabiduría de España y de Austria, Alcalá de Henares: Antonio Vázquez.

- (2015): El maquiavelismo degollado por la cristiana sabiduría de España y de Austria, eds. Luis Felipe Jiménez and Antonio Núñez Martínez, Zacatecas: Texere Editores.

CuRTIUS, E.R. (1955): "El libro como símbolo," in Literatura europea y Edad Media latina, trans. A. Alatorre, México: Fondo de Cultura Económica, pp. 423-89.

DALY, P.M. (2014): The Emblem in Early Modern Europe. Contributions to the Theory of the Emblem, Farnham: Ashgate.

Ferrer de Valdecebro, A. (1658): Gobierno General, Moral y Político, hallado en las fieras y animales silvestres; sacados de sus naturales propiedades, y virtudes, 1658 y su continuación referida a las aves, 1668).

- (1668 = 2007): El porqué de todas las cosas, eds. A. Bernat Vistarini and J.T. Cull, Palma de Mallorca: José J. de Olañeta Editor-UIB. 
FERRER DE VALDECEBRO, A. (1728): Gobierno general, moral y politico hallado en las aves mas generosas y nobles, sacado de sus naturales virtudes y propiedades..., Madrid: Francisco Medel del Castillo.

FreEMAN, R. (1948): English Emblem Books, London: Chatto and Windus.

GABRIELE, M. (1999): "Introduzione," in A. Alciato, Il libro degli emblemi secondo le edizioni del 1531 e del 1534, Milano: Adelphi, pp. xiii-lxxii.

Galino CARrillo, M.Á. (1948): Los tratados de educación de principes. Siglos XVI y XVII, Madrid: CSIC.

GARCÍA DE CASTROJERIZ, J. (1494): Glosa castellana al Regimiento de príncipes.

GARAU, F. (1691): El sabio instruido de la naturaleza, en quarenta máximas políticas, y morales, ilustradas con todo género de erudición sacra, y humana..., Barcelona: En la Imprenta de Antonio Ferrer, y Balthasar Ferrer, libreros.

- (1700): Tercera parte del sabio instruido de la naturaleza, con esfuerzos de la verdad, en el tribunal de la razon; alegados en quarenta y dos maximas, politicas, y morales. Contra las vanas ideas de la politica de Machiavelo..., Barcelona: En la Imprenta de Cormellas, por Thomas Loriente.

- (1709): El sabio instruido de la gracia en varias máximas o ideas evangélicas, políticas y morales, Madrid: Antonio González de Reyes.

GÓmEZ MARTíneZ, J.L. (1979): "Los supuestos modelos de las Empresas de Saavedra Fajardo y su carácter ensayístico," Nueva Revista de Filología Hispánica, 28, pp. 374-384. Consulted online. URL: http://www.cervantesvirtual.com/obra-visor/ los-supuestos-modelos-de-las-empresas-de-saavedra-fajardo-y-su-caracter-ensayistico/html/68af51a6-e1e7-4eca-a269-680e0b2ab4f7_5.html. [5-7-2017].

GuEVARA, Antonio de (1539 and 1541): Epistolas familiares, Valladolid.

- (1520): Relox de príncipes, Valladolid.

- (1994): Relox de príncipes, ed. E. Blanco, Madrid: ABL Editor-Conferencia de Ministros Provinciales de España.

GuZMÁN, F. de (1565): Triumphos morales, Alcalá de Henares: Andrés Angulo.

HENDRICKSON, D.S. (2015): Jesuit Polymath of Madrid: The Literary Enterprise of Juan Eusebio Nieremberg (1595-1658), Leiden: Brill.

JimÉnEZ CASTAÑO, D. (2017): "La filosofía política de Francisco Garau en la Tercera parte del sabio instruido de la naturaleza," in B. Ballester Morell, A. Bernat Vistarini y J.T. Cull (eds.), Encrucijada de la palabra y la imagen simbólicas. Estudios de emblemática, Palma de Mallorca: José J. de Olañeta_Sociedad Española de Emblemática (at press).

LAusberG, H. (1999): Manual de retórica literaria, Madrid: Gredos.

LEDO, J. (2015): "La estética renacentista de la oscuridad: cuatro momentos," Boletín Hispánico Helvético, v. XXV, pp. 95-134

(1603): Libro de las honras que hizo el Colegio de la Compañia de Jesús de Madrid, a la M(ajestad) C(atólica) de la Emperatriz. doña María de Austria..., Madrid: Luis Sánchez.

MAIER, M. (1617): Atalanta fugiens: hoc est Emblemata nova de secretis nature chymica, accommodata partim oculis \& intellectui, figuris cupro incisis, adjectisque sententiis, epigrammatis \& notis, 
partim auribus \& recreationi animi plus minus 50..., Oppenheimii: Ex typographia Hieronymi Galleri, sumptibus Joh. Theodori de Bry.

Maier, M. (2007; 2nd ed. 2017): La fuga de Atalanta, trans. A. López Tobajas and M. Tabuyo, Prologue, J. Godwin, Vilaür: Atalanta.

MartíneZ De LA VegA, J. (1620): Solenes y grandiosas fiestas que la noble y leal ciudad de Valencia ha becho por la beatificación de su santo pastory padre D. Tomás de Villanueva. Al muy ilustre cabildo y canónigos de su santa iglesia metropolitana, Valencia: Felipe Mey.

Mendo, A., S.J. (1662): Principe perfecto y ministros ajustados; documentos politicos y morales, en emblemas..., León de Francia.

MYLIUS, J.D. (1622): Philosopbia reformata continens libros binos. I. Liber in septem partes divisus est... II. Liber continet authoritates philosophorum, Francofurti.

NEUMEISTER, S. (1998): "De la tradición a la invención: la emblemática política en Gracián y Saavedra Fajardo," in J.-P. Etienvre, ed., Littérature et Politique en Espagne aux Siècles d'Or, Paris: Klincksieck, pp. 321-322.

OrobitG, C. (1998): "Le prince mélancolique dans la comedia," in J.-P. Etienvre, ed., Littérature et Politique en Espagne aux Siècles d'Or, Paris: Klincksieck, pp. 269-283.

ORTí, M. A. (1640): Siglo cuarto de la conquista de Valencia, Valencia: Juan Bautista Marçal.

PÉREZ De HerRerA, C. (1598 and 1618): Discursos del amparo de los legitimos pobres..., Madrid: Luis Sánchez.

Purš, I. (2006): "On the Nature of the Emblems in Michael Maier's Fying Atalanta," in B. Bukovinská and L. Slavíč ek (eds.), Pictura Verba Cupit. Sborník Príspèvkio pro Lubomira Konečnébo (Essays for Lubomír Konényý), Praga: Artefactum, pp. 31-46.

RodríGUeZ DE LA Flor, F. (2002): "La máquina simbólica: Picinelli y el ocaso de la teología escolástica hispánica," in H. Pérez Martínez and B. Skinfill Nogal (eds.), Esplendor y ocaso de la cultura simbólica, Zamora: El Colegio de Michoacán, pp. 143-59. SAAVEDRA FAJARDO, D. (1642): Idea de un príncipe político cristiano representada en cien empresas, Milán.

- (1992): Empresas politicas, ed. S. López Poza, Madrid: Cátedra.

SMiTH, P.J. (2005): "Cognition in Emblematic Fable Books: Aegidius Sadeler's Theatrum morum (1608) and its Reception in France (1659-1743)," in K.A.E. Enenkel and W. Neuber (eds.), Cognition and the Book. Typologies of Formal Organisation of Knowledge in the Printed Book of the Early Modern Period, Leiden-Boston: Brill, pp. 161-185.

SOLÓRZANO PEREIRA, J. de (1653): Emblemata centum, regio-politica, Madrid: D. García Morrás. TRuman, R.W. (1999): Spanish Treatises on Government, Society and Religion in the Time of Pbilip II. The 'de regimine principum' and Associated Traditions, Leiden-Boston-Köln: Brill. ViLLAVA, J.F. de (1613): Empresas espirituales y morales, Baeza: Fernando Díaz de Montoya. Whitney, G. (1586): A Choice of Emblems, Leyden: Christopher Plantin. 